\title{
The Changing Landscape of Peace Research: Geographic, Archival, and Digital Spaces
}

Shelley Rose

Cleveland State University, shelley.rose@csuohio.edu

Follow this and additional works at: https://engagedscholarship.csuohio.edu/clhist_facpub

Part of the Digital Humanities Commons, and the History Commons

How does access to this work benefit you? Let us know!

Publisher's Statement

Copyright Wiley 2017. This article originally appeared in Peace \& Change 42, no. 2: 277-290.

doi: $10.1111 /$ pech. 12235

\section{Original Citation}

Rose, Shelley E. 2017. "The Changing Landscape of Peace Research: Geographic, Archival, and Digital Spaces." Peace \& Change 42, no. 2: 277-290.

\section{Repository Citation}

Rose, Shelley, "The Changing Landscape of Peace Research: Geographic, Archival, and Digital Spaces" (2017). History Faculty Publications. 104.

https://engagedscholarship.csuohio.edu/clhist_facpub/104

This Article is brought to you for free and open access by the History Department at EngagedScholarship@CSU. It has been accepted for inclusion in History Faculty Publications by an authorized administrator of EngagedScholarship@CSU. For more information, please contact library.es@csuohio.edu. 


\section{The Changing Landscape of Peace Research: Geographic, Archival, and Digital Spaces by Shelley E. Rose}

This article focuses on the changing nature of the spaces, historical sources, and products of peace research. Specifically, the article explores the future of peace research after the transnational, digital, and biographi cal turns. It addresses the changing formats of sources generated by acti vists, as well as the challenges of digitizing and disseminating these sources. Finally, the article calls for increased attention to the use of digi tal humanities methods, particularly geographic information systems (GIS) techniques, in peace research.

Place matters in peace history. Activists around the world painstakingly select spaces for their actions whether they are private or public, physical or digital. This article focuses on the changing nature of the spaces, historical sources, and products, particularly digital products, of peace research. Building on the 2015 Peace History Conference topic, "Historical Perspectives on War, Peace, and Religion," I explore four themes: first, the relationship of historical peace research to the transnational, digital, and biographical turns; second, the changing format of sources generated by activist communities, from flyers and pamphlets to social media platforms; third, the benefits and challenges of increasing availability, and simultaneous obscuring, of archival sources; and fourth, the need for increased attention to the digital humanities in historical peace research.

Transnational, national, and local networks of individual peace activists and organizations are inherently suited to scholarship that embraces the transnational and digital "turns." As historian Lara Putnam argues in the April 2016 issue of the American Historical Review, these two disciplinary transitions are occurring parallel to each other, yet the increasing availability of digital sources often "decouples data from place." ${ }^{1}$ Putnam debates the benefits and challenges associated with the ability of researchers to read historical documents without 
the necessity of visiting a brick and mortar archive, what she has termed "side-glancing." She asserts such archival visits lend a deeper understanding of each collection's historical context. ${ }^{2}$ While the value of on-location archival experience cannot be ignored, peace historians have been successfully "side-glancing" for years, relying on transnational networks of activists and organizations as roadmaps to useful transnational connections. Furthermore, the transnational turn cannot be seen outside the context of the biographical turn.

Simone Lässig places the biographical turn in the 1980s and shows a new level of analytical quality becoming evident in the 1990s with increased interest in social and cultural history. ${ }^{3}$ Historical peace research fits well with this trajectory, as reflected in the founding moments of the Peace History Society and the International Peace Research Association in 1964 and the Hamburg Working Group for Historical Peace Research in 1984. Peace researchers continue to use biographical analysis to understand the context of protest movements. Leilah Danielson's recent book, American Gandhi: A.J. Muste and the History of Radicalism in the 20th Century, attests to the continued usefulness of biographical lenses in historical peace studies. ${ }^{4}$ David Kaiser also captures the essence of the biographical turn well in his article, "Bringing the Human Actors Back on Stage." 5 Through his examination of the Albert Einstein Niels Bohr debate over quantum mechanics, Kaiser reflects on the need for historians to consider historical agents within the vast network of their connections, that is, their personalities and not just their actions, in order to more fully understand historical context. Kaiser's observation is even more significant for peace research when historians consider Einstein's role in the international peace community, particularly his contributions to the Russell-Einstein Manifesto in $1955 .^{6}$

Beyond historical networks of individual activists, transnational networks of scholars are a key feature of early side-glancing efforts in peace history. Scholarship on early twentieth-century international women's peace networks represents transnational research framed by networks of pacifists and the personalities of early female leaders like American Jane Addams and German Gertrude Baer. Social Justice Feminists in the United States and Germany, edited by Kathryn Kish Sklar, Anja Schüler, and Susan Strasser, reflects the combination of transnational networks of historical subjects as well as a transnational team of editors. Published in 1998, this "dialogue in documents" utilizes the transatlantic correspondence of individual activists to 
illustrate side-glancing within the activist and social justice community. This side-glancing included German activist Alice Salomon's articles and the transnational correspondence about Jane Addams's Twenty Years at Hull House. ${ }^{7}$ In addition, the editors hope the "cross-national dialogue can serve as a model" for the use of activist voices themselves to transcend the boundaries of nation-centered historiographies. ${ }^{8}$ The recent edited volume, Protest Cultures, by Kathrin Fahlenbrach, Martin Klimke, and Joachim Scharloth represents another such effort to connect a transnational group of contributors under the framework of a single volume. ${ }^{9}$

Historian Leila Rupp demonstrates the viability of transnational methods for historical peace research in her 1997 monograph Worlds of Women: The Making of an International Women's Movement. ${ }^{10}$ Rupp focuses on three international organizations of women: the Women's International League for Peace and Freedom (WILPF), the International Council of Women (ICW), and the International Alliance of Women, paying close attention to the ways in which each individual activist contributed to the "collective identity" of these groups. ${ }^{11}$ Transnational networks of activists allow Rupp to "explore the politics of personal interaction," even when global forces of nationalism and conflict shaped the spaces for that interaction, such as the 1919 WILPF meeting protesting the Treaty of Versailles, which was held in Zurich, Switzerland, because German citizens were not allowed in France. ${ }^{12}$

Rupp's "politics of personal interaction" is a tested and effective framework for both traditional publications and emerging digital humanities (or digitally informed) projects. In terms of traditional scholarship, Helmut Donat and Karl Holl's Die Friedensbewegung (The Peace Movement) dictionary and Gisela Brinker-Gabler's document collection, Frauen gegen den Krieg (Women Against War), rely on biographical information and primary source documents that link individual activists conceptually and physically to one another. ${ }^{13}$ The nature of this interaction has changed substantially among activists, accelerated, as Putnam argues, by increasing access to the Internet and diverse social media platforms. Anastasia Kavada, for example, focuses on this phenomenon in her Digital Protest Movements project, which investigates the use of social media networks and related technology in the Occupy Movement. ${ }^{14}$ As Kavada's blog testifies, the digital turn allows scholars to engage with and create digital products surrounding a particular movement or network. 
Putnam is correct to assert that the transnational "turn" is accelerating with the rise of technology and digital humanities, yet to ignore the changing nature of sources produced by historical subjects would be a great disservice to the discipline. For instance, Claire Potter recently addressed the issue of Hillary Clinton's e-mails as a historical source in her essay "Historians Should Care About Secretary Clinton's Emails." Potter argues "as a public figure, records of [Clinton's] private life should also be preserved," and laments the loss of Clinton's e-mails as primary source material. ${ }^{15}$ As individuals, activists seem to have an uncommon understanding of the impact of both physical and ephemeral correspondence: They include flyers (frequently multiple copies), photographs, personal notes, and even protest signs in their personal and organizational archival collections.

\section{CHANGING LANDSCAPE OF SOURCES}

Protest movements and activist communities create a wide array of primary sources in the course of their public and private activities. In the German case, these sources range from hand-drawn posters for the 1927 Munich exhibition "Peace Movements and Peace Activism in All Countries," to websites and social media pages for the German Easter Marches (Ostermarsch Bewegung) in 2016. ${ }^{16}$ Political scientists Paul Nixon and Rajash Rawal place the first use of the Internet for information dissemination with the World Trade Organization protests in Seattle in November 1999. ${ }^{17}$ This event creates a rather neat divide between twentieth-century and twenty-first-century organizing techniques. During the Peace History Society Conference, for example, the 2011 Tahrir Square uprising in Cairo, Egypt, provided a striking lens into the challenges and potential of the role of digital primary sources in twenty-first-century protest movements and protest research.

At the 2015 Peace History Society Conference, historian Stephanie Boyle presented a social media video by Egyptian activist Asmaa Mahfouz, who was credited for calling protestors to Tahrir Square on January 25,2011 . Boyle argues this video was obscured from Western scholars and audiences as a catalyst for the demonstration because of language barriers and the fact that scholars simply were not looking for causes of the revolution on digital platforms. ${ }^{18}$ Lacking the advantage of being physically among protesters in Cairo, Western scholars sought traditional evidence of protest organization in journalism and 
flyers, not immediately recognizing, as geographer Nezar Alsayyad asserts, that the "cyber activists" who called for the protest against police brutality used social media to connect their voices to the "arena of physical space." 19 Side-glancing from the West during the Arab Spring, therefore, actually limited the global understanding of the protest as Putnam cautioned. Transnational observers misunderstood the links between digital and physical spaces of the protest.

Fahlenbrach, Klimke, and Scharloth assert "the emergence of modern mass media in the twentieth century in particular changed the communication of protest in a fundamental way." 20 This increase in digital communication poses the question of how to close the gap between born-digital primary sources, like those created for the Occupy Movement, and printed primary sources that need to be digitized to reach a wider audience, such as flyers, posters, and newsletters from nineteenth- and twentieth-century movements.

\section{AVAILABILITY (AND OBSCURING) OF ARCHIVAL SOURCES}

Peace scholars have reached a pivotal moment: The digital turn challenges us to consider which materials in the geographically scattered collections left by peace activists and organizations are digitized, and when that process will occur. In many ways, the founding goals of the Peace History Society challenge national narratives enforced by established national archival systems. As Lara Putnam demonstrates, however, historians need to be especially careful not to magnify the existing "nation-state bias" as sources become digitized and available beyond national borders. ${ }^{21}$

Norwegian sociologist Johan Galtung wrote in 1969, "the peace researcher has no fatherland." 22 Peace scholars are already accustomed to gathering far-flung sources in their pursuit of the transnational networks inherent to activist communities. Many peace activists eschewed leaving their papers in such repositories, instead choosing, in the German case, grassroots collections such as the APO-Archiv (Extra-Parliamentary Opposition and Social Movements Archive), Hamburger Institut für Sozialforschung (Hamburg Institute for Social Research [HIS]), and the Nonviolence Movement Archive, ArchivAktiv. $^{23}$

Putnam emphasizes the need for place-based learning in the digital turn: "The challenge is to take advantage of the optics and methods that digitization enables while remembering those who stand in the 
shadows, making time for contextualization and spurring the dialogue that counteracts the ignorance of the privileged." ${ }^{24}$ Peace researchers are particularly cognizant of giving a voice to the voiceless, yet the digital turn raises the question of whether place-based research must occur only in physical spaces or if geographic information systems (GIS) methods can fill this role.

The primary mission of peace research, according to Leon Miller, is dissemination. ${ }^{25}$ This goal is closely tied to the political nature of peace research and the activism it documents. Its presence is also clear to any scholar who has sat in an archive flipping through multiple copies of the same or similar flyers, such as those in the extensive APO-Archiv collection at the Free University in Berlin. ${ }^{26}$ If dissemination is a primary goal of both activists and researchers, scholars must determine best practices for accessibility and distribution after the digital and transnational turns. One answer lies in digital humanities projects.

\section{SPATIAL ANALYSIS AND DIGITAL HUMANITIES}

Maps have long been used as sources of spatial information by scholars and nonspecialists alike. Interdisciplinary scholar Tom Koch reasons, "maps are the workbench on which ideas are fashioned in a manner that permits them to be argued and, often, tested." ${ }^{27}$ Historian John Theibault takes this concept further, claiming British physician John Snow's 1854 cholera map "showed that visualizations could serve as both narrative and analysis." ${ }^{28}$ Snow's thematic map of the cholera cases in nineteenth-century London helped physicians and public health officials understand the source of the outbreak, a factor that was not evident outside of this spatial component. As Theibault notes, however, thematic maps using advanced geographic techniques such as choropleth (shading) requires previous knowledge to fully understand. ${ }^{29}$ Digitization makes interaction between text and visualization possible. Theibault cites the "Shaping the West" project by Richard White at the Stanford University Spatial History Project as one effort to present visual spatial historical data on the transcontinental railroad through illustrations and animation. ${ }^{30}$ White's interdisciplinary team recognizes the need to contextualize the geographic information on his site, using various text boxes, yet the project reveals the structural need for fluid links between narrative text and geographic data in digital projects. 
Interdisciplinary collaboration between scholars is increasing; however, the perceived divides between visual products, such as maps, and narrative products remain a critical challenge. Two 2016 edited volumes, Protest Cultures and Spaces of Contention: Spatialities and Social Movements, illustrate this gap well. In Protest Cultures, historian Matthias Reiss stresses "future [street protest] research needs to expand and intensify the dialogue and exchange between the different academic disciplines." Reiss recognizes the potential of interdisciplinary collaboration and cites the 2013 volume, Demonstrations, edited by sociologist Olivier Fillieule and historian Danielle Tartakowsky as an example of this approach. ${ }^{31}$ Reiss is correct to notice that visual sources, and I also argue methods, are "underutilized" in protest movement research.

In the social sciences, Spaces of Contention brings sociologists, geographers, and political scientists together under the common rubric of providing "a state-of-the-art analysis of how space plays a constituting role in social movement mobilization." ${ }^{32}$ While the interdisciplinary contributors employ an impressive array of spatial techniques from sociology, geography, and political science, the volume is grounded in the relationship between space and the organization of protest movements. Sociologist Dingxin Zhao, for example, concentrates on the "built environment" of universities, but does not engage with protestors drawing on narratives related to the collective memory of university spaces or the construction of specific narratives. ${ }^{33}$ As a sociologist, Zhao is focused on the relationship between protesters and the physical limits of the spaces they occupy.

The future of historical peace research in digital humanities lies at the intersection of history and the social sciences. Political scientists Donatella della Porta, Maria Fabbri, and Gianni Piazza's chapter "Putting Protest in Place: Contested and Liberated Spaces in Three Campaigns" reveals the creation of common movement narratives through the experience of shared space, such as in the "No TAV" (Treno Alta Velocità) High Speed Train movement in Italy. These scholars carefully document growing feelings of community among protestors who became "space producers" in long-term camps on the Strait of Messina. ${ }^{34}$ The camps provided "daily face-to-face interactions" that "created human and political relationships," according to della Porta, Fabbri, and Piazza, revealing complex connections between individual activists and the spaces they occupy. 
Shared experiences in a common space are a persistent theme in protest movement research. In a recent interview, historian and antiVietnam activist David Goldberg discussed the power of shared spaces for galvanizing a movement identity and a sense of community. The demonstrations themselves were not the only spatial factor; Goldberg describes the disappointment experienced by protesters who returned to their individual routines, feeling isolated and ineffectual. ${ }^{35}$ This postprotest experience reflects the power of spatial proximity and explains the heightened sense of community among long-term events such as the Italian No TAV movement.

Interdisciplinary conversations surrounding the use of space in protest movements must draw on historians to analyze narratives created by the intentional occupation of space by activists. The Protest Spaces digital humanities project provides a starting point for combining narrative and spatial analysis. ${ }^{36}$ The project focuses on three types of protest spaces: (1) issue-specific spaces, such as the German Easter March Movement focus on military bases; (2) collective memory sites occupied specifically to draw on existing historical narratives, such as the Frankfurt Paulskirche and Washington Mall; and (3) transnational movements that created a shared spatial experience in order to construct a collective narrative among organizers and audiences, such as the Committee for Nonviolent Action's (CNVA) San Francisco to Moscow Walk for Peace.

Issue-specific protest spaces are locations linked by proximity to the focus of a protest event. Historian Susanne Schregel illustrates the effective use of military sites, such as the Cold War-era Pershing missile base Mutlangen, for protests against stationing NATO nuclear weapons in West Germany in the 1980s. While the military sites themselves were new locations for protest, sparked by the new policy, activists inscribed place meaning on the sites and created a common movement narrative. This process of inscribing a place-based narrative on existing space is evident in signs such as "Pershing Macht Frei" (Pershing [Missiles] Set You Free), purposefully reminiscent of the sign above the Auschwitz-Birkenau Nazi Concentration Camp. ${ }^{37}$

The German Easter March Movement (Ostermarsch Bewegung) historically staged protests at nuclear weapons bases in West Germany as well. After participating in the 1959 March to Aldermaston in England, Hans-Konrad Tempel founded the first West German march in Hamburg, Germany, in 1960 and recalls looking at maps to find nuclear missile sites for a potential protest space, eventually finding 
information on the Bergen-Hohne site. Over the course of four days, over one hundred marchers walked from Hamburg to the NATO military base in Bergen-Hohne. Protesters gathered under the slogan "Against atomic weapons of any kind or in any nation in the East or West," preferring to emphasize the participation of individuals, not organizations. $^{38}$

While the protesters focused on the specific space of military bases, Easter March organizers realized in subsequent years that concluding rallies drew a significantly larger crowd in the major city centers than in the often rural sites of the bases. Accordingly, Easter March routes were flipped after 1961. Protesters began their journey at military sites and marched to city center all over West Germany. ${ }^{39}$

The second type of protest space, collective memory sites, or Erinnerungsorte in German, are often only indirectly related to the topic of specific protest movements. In fact, activists choose these sites for the place meaning already inherent in the space, such as the National Mall in Washington, D.C. and the Paulskirche (St. Paul's Church) in Frankfurt, Germany. The National Mall is already the focus of an ambitious digital humanities project, Histories of the National Mall, sponsored by the Roy Rosenzweig Center for History and New Media. While Histories of the National Mall joins narrative with spatial analysis, it does so with individual items organized alphabetically and chronologically. Items on the site map include protest events, such as the "Moratorium to End the War in Vietnam" in November 1969, yet their descriptions are typically limited to summaries of the events and do not problematize the use of the National Mall and its place identity. ${ }^{40}$ As users browse through categories like "People" and "Past Events," or tags including "politics and protest," they encounter few cohesive narratives linking each item. The National Mall team does engage with narratives about the space as a site for protest in the "Explorations" category with the research question, "How have protests on the Mall changed over time?" 41 This narrative is an important step to linking visual data with historical narrative, yet it remains grounded in the social science understandings of space seen in Spaces of Contention.

The National Mall protest narrative focuses on the physical spaces of the Mall and how these spaces changed over time from small gardens and winding paths to the open space familiar to visitors today. This interpretation neglects important research on the concept of place by geographers beginning in the 1980s. Protest Spaces, on the other 
hand, builds on this understanding of the physical spaces for demonstrations, considering the spaces like the National Mall not only as sites for various protest movements, but also the peaceful transfer of political power, such as Barack Obama's 2009 presidential inauguration attended by 18 million people. ${ }^{42}$ The collective memory of the National Mall as a site of the democratic process fuels the use of the site by activists, a phenomenon evident in the German context at the Frankfurt Paulskirche.

Like the National Mall, the Frankfurt Paulskirche represents a site of political promise and democratic spirit. The church was the site the Frankfurt National Assembly in 1848, which, although unsuccessful in establishing democracy, many Germans identify as a precursor to German unification in $1871 .{ }^{43}$ Due to this national legacy, the Paulskirche was among the first buildings reconstructed in World War II-devastated Frankfurt. Various activist groups used the iconic space as a site for rallies after 1945, recognizing the church's significance in collective memory as a site of early German democratic will. In addition, the repeated use of the Paulskirche added layers of meaning to the already significant place identity of the site. ${ }^{44}$

The third protest space consists of transnational movements that created shared spatial experiences and constructed a collective narrative among organizers and audiences, such as the Committee for Nonviolent Action's (CNVA) 19601961 San Francisco to Moscow Walk for Peace. In Protest Spaces, Jared Donnelly maps the stops of this transnational movement, visually emphasizing the transnational structure of the walk as a protest event. ${ }^{45}$ Staged during the Cold War, CNVA organizers relied on transnational networks to cross borders otherwise blocked by tense political relationships. Calling for "unilateral disarmament, the end of conscription and a universal guarantee of civil rights," CNVA activists created a dialogue and collective identity through shared protest spaces across the United States and Europe. ${ }^{46}$

The CNVA Walk for Peace relied on the everyday interactions between individuals that della Porta, Fabbri, and Piazza argue are critical to collective identity formation through shared spaces. Not only did CNVA marchers share the space of the transnational march route, they stopped along the way to distribute leaflets and sought the cooperation of local activists. ${ }^{47}$ While Donnelly documents tension between the American marchers and the local activists, particularly in West Germany, this friction marks the process of constructing a collective 
identity for the march through various national and international contexts. When the marchers arrived in Moscow, they were greeted respectfully and able to distribute leaflets to crowds in the Russian capital. $^{48}$ While the construction of a transnational narrative in national spaces frequently proved difficult, Donnelly maintains that the march demonstrates the effectiveness of transnational protest events.

\section{CONCLUSION}

As illustrated by the Protest Spaces and Histories of the National Mall projects, spatial analysis of protest events reveals the tremendous potential of digital humanities tools for the future of historical peace research. While Lara Putnam expresses concern that digital tools such as keyword searches and digitized archival collection may "decouple" data from its place of origin, conscientious projects like Protest Spaces anchor events and archival information through the use of maps. ${ }^{49}$ Furthermore, digital humanities techniques connect the rich peace research that embraces the transnational, digital, and biographical turns and fosters connections between data visualization, in this case geographic data, and the construction of historical narratives by both activists and scholars.

\section{NOTES}

1. Lara Putnam, "The Transnational and the Text Searchable: Digitized Sources and the Shadows They Cast," American Historical Review 121, No. 2 (April 1, 2016): 377. doi:10.1093/ahr/121.2.377. Hereafter cited as Putnam, "Transnational."

2. Ibid., 380 .

3. Volker Berghahn and Simone Lassig, Biography between Structure and Agency: Central European Lives in International Historiography (New York: Ber ghahn Books, 2008), 3.

4. Leilah Danielson, American Gandhi: A.J. Muste and the History of Radi calism in the Twentieth Century (Philadelphia, Pennsylvania: University of Pennsyl vania Press, 2014).

5. David Kaiser, "Bringing the Human Actors Back on Stage: The Personal Context of the Einstein Bohr Debate," in The British Journal for the History of Science, 27:2 (1994): 129152.

6. Bertrand Russell and Albert Einstein, "The Russell Einstein Manifesto," July 9, 1955. ID: peace6.007.5 in "Published Papers and Official Documents," Linus Pauling and the International Peace Movement. Accessed July 1, 2016. 
7. Kathryn Kish Sklar, Anja Schuler, and Susan Strasser, Social Justice Femi nists in the United States and Germany (Ithaca, New York: Cornell University Press, 1998), 168 174. Hereafter cited as Sklar, Schuler, and Strasser, Social Jus tice.

8. Ibid., 2.

9. Kathrin Fahlenbrach, Martin Klimke, and Joachim Scharloth, eds. Protest Cultures: A Companion (New York: Berghahn Books, 2016). Hereafter cited as Fahlenbrach et al., Protest Cultures.

10. Leila J. Rupp, Worlds of Women: The Making of an International Women's Movement (Princeton, New Jersey: Princeton University Press, 1997). Hereafter cited as Rupp, Worlds of Women.

11. Ibid., 7.

12. Ibid., 11.

13. Helmust Donat and Karl Holl, Die Friedensbewegung: Organisierte Pazi fismus in Deutschland, Osterreich und in der Schweiz (Dusseldorf: ECON Taschen buch Verlag, 1983); Gisela Brinker Gabler, Frauen gegen den Krieg (Frankfurt am Main: Fischer Taschenbuch Verlag, 1980).

14. Anastasia Kavada, Digital Protest Movements. www.digitalprotest.net. Accessed February 10, 2017.

15. Claire Potter, "Historians Should Care About Secretary Clinton's Emails," Public Seminar. http://www.publicseminar.org/2016/07/historians should care ab out secretary clintons emails/. Accessed July 7, 2016.

16. Folder 7, Poster Collection, Ludwig Quidde/Deutsches Friedenskartell Papers, League of Nations Archive, United Nations Library, Geneva. www.osterma rsch Info.de. http://www.ostermarsch info.de/.

17. Paul Nixon and Rajash Rawal, "Cyberspace," in Protest Cultures, eds. Fahlenbrach et al., 307.

18. Stephanie Boyle, "The People Demand: Media, Religion and Gender and the Egyptian Revolution of 2011" (paper presented at the Peace History Society Conference, Hartford, Connecticut, October 22 24, 2015).

19. Nezar Alsayyad, "The Virtual Square: Urban Space, Media, and the Egyp tian Uprising," Harvard International Review 34:1 (Summer 2012): 62.

20. Kathrin Fahlenbrach, Martin Klimke, and Joachim Scharloth, eds. "Intro duction," in Protest Cultures: A Companion (New York: Berghahn Books, 2016), 3.

21. Putnam, 381.

22. Quoted in Heikki Patomaki, "The Challenge of Critical Theories: Peace Research at the Start of the New Century," Journal of Peace Research 38, No. 6 (2001): 730 .

23. See this comprehensive list for examples of German archives at the Archiv fur alternatives Schrifttum website. http://afas archiv.de/vda.html. Accessed July 7, 2016.

24. Putnam, 397.

25. Leon Miller, "Peace Research in the Digital Age," International Journal on World Peace 29, No. 2 (June 2012): 19. Here Miller refers to early Peace His tory Society leader Charles Chatfield's 1979 article "International Peace Research: The Field Defined by Dissemination." Charles Chatfield, "International Peace 
Research: The Field Defined by Dissemination," Journal of Peace Research 16, No. 2 (1979): 163179.

26. The APO Archiv houses approximately 1300 meters of material on extra parliamentary activism in Germany. This includes 6125 broschuren (flyers, pam phlets, and leaflets). Siegward Lonnendonker, "Archivbestand. Einleitende Bemerkungen," APO und soziale Bewegungen (APO Archiv). http://web.fu be rlin.de/APO archiv/Index.htm. Accessed February 10, 2017.

27. Tom Koch, "Visualizing Disease: Understanding Epidemics Through Maps," ArcUser (Spring 2011): 65. http://www.esri.com/news/arcuser/0311/files/dis easemap.pdf. Koch holds an interdisciplinary $\mathrm{PhD}$ in geography, medicine and phi losophy/ethics. See "Tom Koch," Department of Geography, The University of British Columbia. http://www.geog.ubc.ca/persons/tom koch/.

28. John Theibault, "Visualizations and Historical Arguments," in Writing History in the Digital Age, eds. Kristen Nawrotzki and Jack Dougherty (Ann Arbor, Michigan: University of Michigan Press, 2013) doi:https://doi.org/10.3998/dh. 12230987.0001.001.

29. Theibault, "Visualizations."

30. Richard White, Celena Allen, and Erik Steiner, "Shaping the West," Spa tial History Project, Stanford University. http://web.stanford.edu/group/spatialhis tory/cgi bin/site/project.php?id=997. Accessed February 10, 2017.

31. Matthias Reiss, "Street Protest," in Protest Cultures, eds. Fahlenbrach et al., 357 358. See also Olivier Fillieule and Danielle Tartakowsky, eds. Demonstra tions, trans. Phllis Aronoff and Howard Scott (Halifax, Nova Scotia, 2013).

32. Walter Nicholls, Justin Beaumont, and Byron A. Miller eds., Spaces of Contention [electronic Resource]: Spatialities and Social Movements (Farnham, Sur rey: Ashgate, 2013), 3. Hereafter cited as Nicholls et al., Spaces of Contention.

33. Dingxin Zhao, "The Built Environment and Organization in Anti US Pro test Mobilization after the 1999 Belgrade Embassy Bombing," in Nicholls et al., Spaces of Contention, 199218.

34. Donatella della Porta, Maria Fabbri, and Gianni Piazza, "Putting Protest in Place: Contested and Liberated Spaces in Three Campaigns," in Nicholls et al., Spaces of Contention, 43, 29.

35. “David Goldberg interview, 15 June 2016," Cleveland Regional Oral His tory Collection. Interview 750001, approximately minute 34:00. http://engagedschol arship.csuohio.edu/crohc000/763. Accessed July 8, 2016.

36. Shelley E. Rose, Jared R. Donnelly, and Philipp Gassert, Protest Spaces: Peace Movements in the United States and Germany, 1921 2000. www.prote stspaces.org. Hereafter cited as Protest Spaces. Accessed February 10, 2017.

37. Susanne Schregel, "Orte der Friedensbewegung," in Entrustet Euch!" Nuklearkrise, NATO Doppelbeschluss und Friedensbewegung, eds. Christoph Becker Schaum, Philipp Gassert, Martin Klimke, Wilfried Mausbach, and Marianne Zepp (Paderborn: Schoningh, 2012), 172174.

38. Johannes Bastian, "Ein Blick in die Geschichte der Friedensbewegung" Westermanns Padogogische Beitrage 34 (1982): 121 122. Hereafter cited as Bas tian, "Ein Blick in die Geschichte der Friedensbewegung."

39. Maps of the Easter March routes feature prominently in publicity after 1961. See "Ostermarsch 1966 in Deutschland/ Vietnam: Was soll daraus werden?" 
Frieden Ostermarsch Box 2, Ostermarsch Sammlung, APO Archiv, Freie Universitat Berlin for an example.

40. "Moratorium to End the War in Vietnam," Histories of the National Mall. http://mallhistory.org/items/show/220. Accessed August 11, 2016.

41. "Histories of the National Mall | How Have Protests on the Mall Changed over Time?" http://mallhistory.org/explorations/show/how have protests changed over. Accessed February 10, 2017.

42. "Histories of the National Mall $\mid$ How Has the Audience for Presidential Inaugurations Changed since 1800?” http://mallhistory.org/explorations/show/pres inaugurations. Accessed February 10, 2017.

43. Jonathan Sperber, The European Revolutions 18481851 (Cambridge: Cambridge University Press, 1994), 128129.

44. See the Paulskirche exhibit in Protest Spaces, http://protestspaces.org/neat line/show/paulskirche. For an extended analysis of the negotiation of place identity at the Paulskirche, see Shelley E. Rose, "Place and Politics at the Frankfurt Pauls kirche after 1945," Journal of Urban History 42, No. 1 (January 2016): 145161.

45. Jared R. Donnelly, "Committee for Nonviolent Action San Francisco to Moscow Walk for Peace," in Protest Spaces. http://protestspaces.org/neatline/show/ committee for nonviolent action san francisco to moscow walk for peace.

46. Donnelly, "Staying Civil: Conscientious Objection and Civil Society in West Germany, 1956 1966,” (PhD diss., Texas A \& M University, 2015), 202. See also Donnelly, "Through the Iron Curtain: West German Activists and the 1961 San Francisco to Moscow Walk for Peace," Moving the Social (forthcoming).

47. Ibid., 202232.

48. Ibid., 233234.

49. Putnam, "Transnational," 377.

Pre-print standardized by MSL Academic Endeavors, the imprint of the Michael Schwartz Library at Cleveland State University, 2017 